\title{
Leder for temanummer Friluftsliv, dannelse, lcering og didaktikk
}

\author{
Petter Erik Leirhaug ${ }^{1 \star}$ og André Horgen ${ }^{2}$ \\ ${ }^{1}$ Norges idrettshøgskole, Norge; ${ }^{2}$ Universitetet $i$ Sørøst-Norge, Norge
}

Forum for friluftslivsfag $i$ høyere utdanning har tradisjon for å arrangere et årlig seminar den første uken i januar. Etter et initiativ fra NTNU ved Egil Galaaen Gjølme i tilknytning til seminaret i 2021, som var lagt til Trondheim, ble undertegnede forespurt av redaksjonen i JASEd, ved professor Ellen Beate Hansen Sandseter, om å være gjesteredaktører for et temanummer om friluftsliv i lærings-, dannings- og utdanningskontekster. I forkant av seminaret ble det sendt ut invitasjon til deltagerne om å bidra med artikler til temanummeret Friluftsliv, dannelse, lering og didaktikk. Selv om seminaret ble avlyst på grunn av koronasituasjonen, ble det besluttet å opprettholde planen for temanummeret. Endelig frist for å levere artikkelmanus til temanummeret ble satt til 15. mars 2021. Totalt mottok redaksjonen tjuefem manus innen fristen. Vi må innrømme at antallet innsendte bidrag var overraskende stort, men tolker det samtidig som en gledelig indikasjon på stadig voksende forskning rundt friluftslivspedagogiske praksiser, dannings- og læringsperspektiver. Dette forskningsfeltet er fortsatt ungt, og det er derfor å regne som en milepæl for forskning og kunnskapsproduksjon når JASEd nå utgir det som er det første norske temanummer et om friluftsliv i et vitenskapelig tidsskrift. Fire manus ble vurdert som ikke relevante, mens resterende tjueen ble sendt til fagfeller for vurdering.

Bearbeidingsprosess og fagfellevurderinger viste seg å trekke ut, også her delvis knyttet til koronasituasjonen. Dette har ført til at noen artikler fortsatt er i omløp. Sammen med hovedredaksjonen i JASEd har vi som gjesteredaktører derfor besluttet å presentere sju artikler i dette temanummeret og presentere det som del 1. I lys av mål om å styrke friluftsliv som faglig forskningsfelt innen læring og utdanning er det vårt håp at de fleste av artiklene som fremdeles er under bearbeiding vil finne sin form, og at vi dermed kan presentere JASEd-temanummer et Friluftsliv dannelse, laring og didaktikk del 2 om ikke så altfor lenge. Vi vil allerede her rette en stor takk til de totalt trettisju fagfellene som har vært involvert i prosessen. Uten deres velvilje

\footnotetext{
^Korrespondanse: Petter Erik Leirhaug, e-post: petterel@nih.no

(C) 2022 P. E. Leirhaug \& A. Horgen. This is an Open Access article distributed under the terms of the Creative Commons Attribution 4.0 International License (https://creativecommons.org/licenses/BY/4.0/), allowing third parties to copy and redistribute the material in any medium or format and to remix, transform, and build upon the material for any purpose, even commercially, provided the original work is properly cited and states its license.

Citation: P. E. Leirhaug $\mathcal{E}$ A. Horgen. "Leder for temanummer Friluftsliv, dannelse, lering og didaktikk». Fournal for Research in Arts and Sports Education, Special issue: Friluftsliv, dannelse, laring og didaktikk, Vol. 6(1), 2022, pp. 1-3. 


\section{P. E. Leirhaug $\mathcal{E}$ A. Horgen}

og innsats hadde vi ikke hatt noe temanummer. Videre rettes en stor takk til alle forfatterne, både de som har fått innsendte manus refusert, de som nå blir publisert og de med manus som ennå er i omløp. Foreliggende del 1 av temanummeret består av sju artikler:

I første artikkel spør Inger Margrethe Tronstad og Idar Lyngstad hva friluftslivslærere er opptatt av og praktiserer når de organiserer elever på lengre friluftslivsturer med overnatting. Tydelige avklaringer, dialog og god samtale med alle elevene, samt bruk av rutiner og symbolorganisering, viser seg gjennomgående i uttrykt praksis. På lengre turer hvor elever lever tett med hverandre er det ikke uvanlig at det oppstår gnisninger, og det kommer fram hvordan friluftslivslærere bruker konfliktperioder til å bedre klassemiljøet. Forfatterne bruker empirien til å utdype hvordan organisering ikke bare handler om teknisk-pedagogiske grep, men også er et verdiladet begrep.

I den andre artikkelen skriver Kristian Abelsen og Petter Erik Leirhaug om Dedikerte lerere med bål på timeplanen $i$ videregående skole. Artikkelen handler om hvordan og hvorfor det arbeides didaktisk med bål i videregående skole, og hva bålet kan bidra med i faglige sammenhenger. Utgangspunktet er et aksjonsforskningsprosjekt, og i artikkelen belyses lærere og elevers erfaringer med bruk av bål i friluftslivsundervisningen i kroppsøvingsfaget. Empirien er samlet inn gjennom spørreundersøkelse som henvender seg til elever, samt kvalitative intervju med lærere. Bålet engasjerer, kan skape mestringsfølelse og engasjerer elever både individuelt og kollektivt. Slik viser forfatterne hvordan didaktisk arbeid med bål kan gjøres meningsfullt og relevant.

Tredje artikkel er skrevet på engelsk og har tittel How does a primary school organize outdoor swimming and water safety lessons? Den er skrevet Torbjørn Lundhaug og Hege Randi Eriksen og undersøker hvordan en barneskole organiserte en uke med utendørsopplæring hvor utendørs svømming og vannsikkerhet stod sentralt. Denne friluftslivpraksisen var en del av programmet for faget kroppsøving. Ut fra videoobservasjon fra utendørsopplæringen og fotoeliciteringsintervjuer med to lærere og en rektor, kommer det fram hvordan friluftslivspraksisen og utendørsopplæringen, i det vi vel må omtale som en tidsmessig relativt stor satsing på vegne av friluftsliv i kroppsøving, samsvarte godt med læreplanens kompetansemål om å lære å være trygg $i$, på og rundt vann.

I artikkelen "... the thought that I could flip and die today made me feel anxious" skriver Sabrina Krogh Schmidt, Matt Barker og Fennifer Bryne om læring i elvekajakk. De tre forfatternes utgangspunkt er at det å lære å padle elvekajakk som regel finner sted i et stressende naturmiljø med turbulent «hvitt vann». På den bakgrunnen har de undersøkt elvekajakk-kursdeltakeres opplevde følelser under kursforløp. Empirien er innsamlet gjennom en spørreundersøkelse blant friluftslivsstudenter fra New Zealand. Deltakerne gav uttrykk for intense følelser som frykt og engstelse underveis, særlig i forkant av selve aktiviteten. Funnene i undersøkelsen kan informere lærere, instruktører og kursarrangører om hvordan de kan adressere og redusere unødvendig 
engstelse. Artikkelen kan også skape refleksjon rundt frykt, læring og personlig vekst i relasjon til utvikling av kursprogrammer og praktisk-didaktisk tilnærming.

Pernille Bartnees og Anne Myrstad starter artikkelen Knowing-with-snow in an outdoor kindergarten med en fortelling om Vilde som smaker på snø. Artikkelen er resultat av feltarbeid med varighet fra oktober til mai i en barnehage nord i Norge. Uteområdet var i hele perioden dekket av snø, og møtet med snøen blir analysert som eksempel hvordan barns møter $i$ og med omgivelsene kan forstås og verdsettes som læringsprosesser. Forfatterne benytter Tim Ingolds begrep korrespondanse for å utforske hvordan ulike elementer gjensidig påvirker hverandre og hvordan barn lærer gjennom å være i verden. Vi får presentert nyanser som kan bidra til utvikling av pedagogens rolle i utendørs omgivelser i barnehagens praksis.

Barndommens landskap er tittelen på den neste artikkelen, skrevet av Merete Lund Fasting, Fannicke Høyem og Annette Bischoff. De undersøker hvilke minner som kommer til uttrykk når unge voksne møter barndommens nærnatur i voksen alder, og drøfter hvordan disse minnene kan forstås. Sammen med en av forskerne har åtte unge voksne har gått tilbake til sine barndomssteder i skolens nærnatur sammen med en av forskerne. Det legges vekt på hvordan steder skaper minner, gir resonans og at kroppen bærer med seg spor av stedene vi har kjent. Gjennom dette viser forfatterne hvordan de unge voksnes kroppslige utforskning giennom lek og friluftsliv i barndommen har vært avgjørende for dannelsen av det de betegner som barndommens landskap. Det argumenteres for at stedsidentitet, formet gjennom friluftsliv og lek i barndommens landskap, kan gi tilhørighet, forankring og resonans i en omskiftelig verden.

I temanummerets siste artikkel, Learning leadership in outdoor education: Effects of feedback, er målet å undersøke fremgang i opplevde lederegenskaper hos studenter på et seks måneders utendørs lederutdanningskurs, og å undersøke effekten av systematisk tilbakemelding fra medstudenter. Forfatterne AgeVigane og Sindre M. Dyrstad har randomisert totalt 17 studenter i intervensjons- og kontrollgrupper, der intervensjonen besto av systematisk bruk av tilbakemeldinger fra medstudenter. Resultatene viser betydelig fremgang for alle studenter i opplevd egenutvikling relatert til utendørs ledelse, mens tilbakemelding fra medstudenter ikke synes å ha betydning for denne forbedringen i opplevde lederegenskaper. Ulike årsaker til resultatene diskuteres og belyser utfordringer med bruk av medstudenttilbakemeldinger i utendørs ledelsesprogrammer.

De sju artiklene viser samlet sett noe av bredden i fagfeltet friluftsliv og friluftslivsutdanning, både i form og innhold. Vi håper de kan være av betydning for debatt, kunnskapsforståelse og inspirasjon til videre forskning.

God lesning!

Petter Erik Leirhaug og André Horgen 